\title{
MODIFICATION OF CLASTS IN LODGEMENT TILLS BY GLACIAL EROSION
}

\author{
By Martin Sharp \\ (Department of Geography, University of Aberdeen, Old Aberdeen AB9 2UF, Scotland)
}

\begin{abstract}
B-axis diameter of $>32 \mathrm{~mm}$ in lodgement tills from Skálafellsjökull, south-east Iceland, had a stoss-and-lee form. Clasts deeply embedded in the tills were more likely to have such a form than those resting lightly on the surface. Deeply embedded basalt and andesite clasts were also more rounded than lightly embedded clasts of similar lithology, and more striated and more likely to have a stoss-andlee form than deeply embedded gabbro and granophyre clasts. Lightly embedded basalt and andesite clasts were more striated than lightly embedded gabbro and granophyre clasts. Within each lithological class, larger clasts were more likely to have a stoss-and-lee form. It is suggested that deeply embedded boulders acquire their rounded stoss-and-lee form by abrasion and fracture by over-riding debris-laden ice. This occurs after they have become firmly lodged by ploughing into the subglacial till bed, and before they become buried by lodgement of debris around them. The degree of modification depends in part upon clast size and lithology. The long-axis orientation of deeply embedded boulders is a good indicator of former ice-flow directions.
\end{abstract}

RÉSUMÉ. Modification des galets dans les dépôts en niches par l'erosion glaciaire. 7,8\% de 1105 galets avec un diamètre suivant l'axe B supérieur à $32 \mathrm{~mm}$ dans des dépôts en niches issus du Skálafellsjökull, dans le Sud-Est de l'Islande ont une forme allongée dans le sens du courant glaciaire. Les cailloux profondément enfoncés dans les dépôts ont plus de chance d'avoir une telle forme que ceux restant près de la surface. Les éclats de basalte et d'andésite profondément enfouis sont également plus arrondis que ceux de lithologie semblable qui sont peu enterrés, ils sont plus striès et ont plus de chance d'avoir une forme allongée dans le sens du courant glaciaire que les morceaux profondéments enfouis de gabbros et de granophyre. Les morceaux de basalte et d'andésite peu enfouis sont plus striés que ceux de gabbro et de granophyre peu enfouis. A l'intérieur de chaque classe lithologique, les plus grands fragments ont plus de chance d'avoir une forme allongèe dans le sens du courant glaciaire. On suggère que les blocs profondément enfouis acquièrent leur forme dans le sens du courant de glace, arrondie par abrasion et fracture lorsqu'ils sont surmontés par de la glace chargèe de matériaux. Ceci arrive après qu'ils se soient solidement amarrés en se plantant dans le dépôts du lit sousglaciaire, et avant qu'ils aient èté à leur tour enterrés par l'installation de débris autour d'eux. L'importance de la modification dépend en partie de la taille et de la nature lithologique des cailloux. L'orientation du grand axe des blocs profondement enfouis est un bon indicateur de la direction de l'écoulement passé de la glace.

ZuSAMmEnfassung. Veränderung von Gesteinbrocken in Moränenablagerungen durch glaziale Erosion. $7,8 \%$ von 1105 Gesteinsbrocken mit B-Aschenlängen von mehr als $32 \mathrm{~mm}$ in Moränenablagerungen des Skálafellsjökull in Südost-Island besassen Stromlinienform. Dies traf für tief in die Moräne eingebettete Brocken häufiger zu als für oberflächennahe. Tief eingebettete Basalt- und Andesit-Brocken waren auch stärker abgerundet als oberflächennahe ähnlicher Konsistenz; sie waren ausserdem stärker gekritzt und besassen ausgeprägtere Stromlinienform als tief eingebettete Gabbro- und Granophyr-Brocken. Oberflächennahe Basalt- und AndesitzBrocken waren stärker gekritzt als solche aus Gabbro und Granophyr. Innerhalb einer lithologischen Klasse hatten grössere Brocken häufiger eine Stromlinienform. Es wird vermutet, dass tief eingebettete Blöcke ihre abgerundete Stromlinienform durch Abrasion und Bruch erhalten, wenn sie von schuttbeladenem Eis überfahren werden. Dies tritt ein, wenn sie durch ihr Einpflügen in die Grundmoräne fest gelagert sind und bevor sie durch Ablagerung von Schutt um sie herum begraben werden. Das Ausmass der Veränderung hängt teilweise von ihrer Grösse und Zusammensetzung ab. Die Längsachse tief eingebetteter Blöcke ist ein guter Indikator für frühere Eisflussrichtungen.

\section{INTRODUCTION}

Boulton (1978) has suggested that when large boulders with a smoothed and striated, often 
bullet-nosed up-glacier termination, and an abruptly truncated down-glacier termination (henceforth termed a stoss-and-lee form), and a single well-defined set of striae which diverge slightly in a down-glacier direction are found in a till unit, then that unit is probably a lodgement till. The long-axis orientation of such boulders has been used as an indicator of ice-flow direction by Krüger (1979).

A boulder which ploughs deeply into the subglacial till bed during lodgement may cease to move relative to over-riding debris-rich glacier ice and offer a steady unrotating resistance to ice flow. A steady-flow pattern is set up around the boulder, and its up-glacier face is abraded and streamlined by debris-rich basal ice. If the ice digs into the till on the boulder's up-glacier side, a bullet-nosed end may develop. The lee-side surface of the boulder may be a remanie surface, which has not suffered erosion, or may be shaped by fracture at a point of contact with large over-riding particles, if cavitation has occurred around the boulder, leaving its lee side unsupported (Boulton, 1978) (Fig. 1).

The aim of the present study was to investigate the extent to which such erosional modification of large clasts occurs in lodgement tills at Skálafellsjökull, south-east Iceland (lat. $65^{\circ} 16^{\prime} \mathrm{N}$., long. $16^{\circ} 05^{\prime} \mathrm{W}$.). In particular, the influence of size and lithology of clasts was examined.

\section{METHODS}

To determine whether the morphology of deeply embedded boulders was significantly

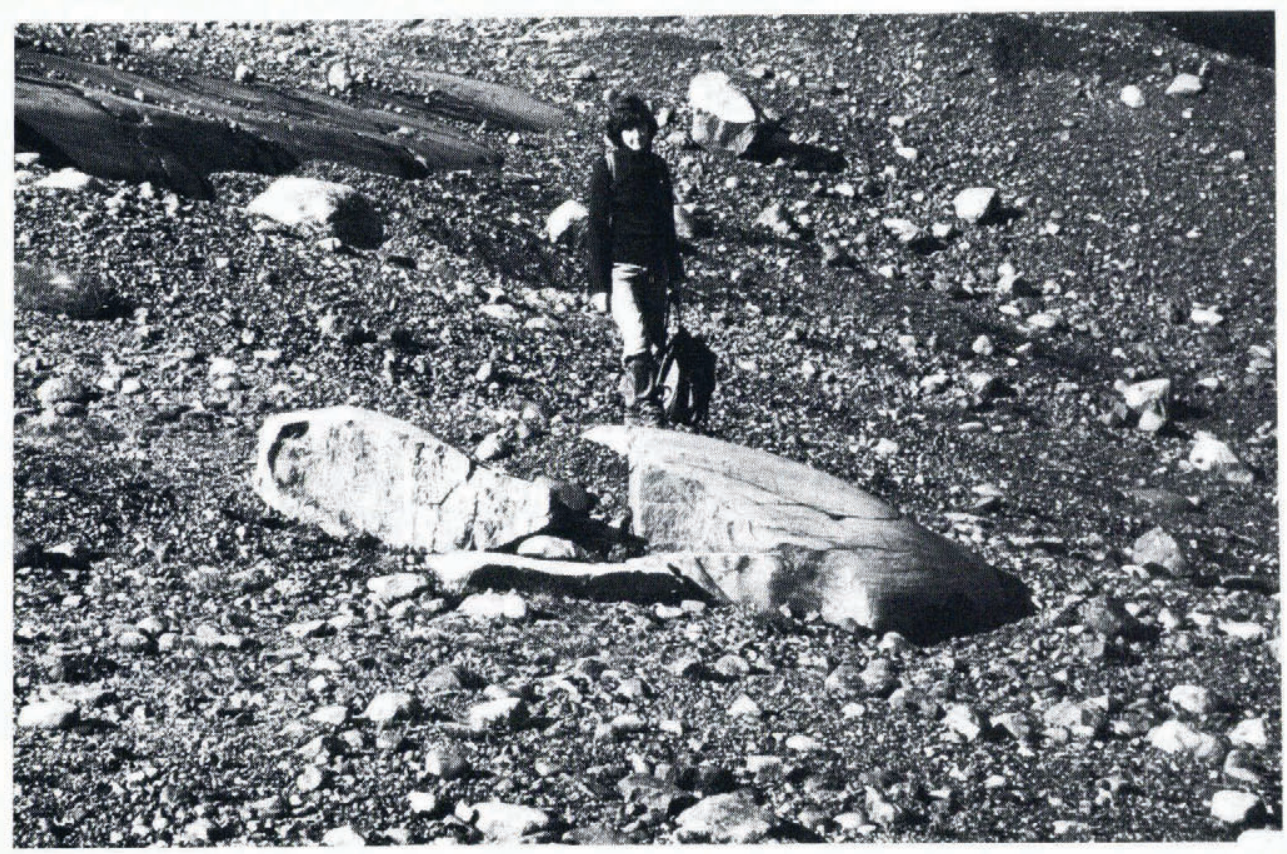

Fig. I. Streamlined, deeply embedded boulder with stoss-and-lee form. Large angular fragments derived from the lee side of the boulder lie on the till surface at the foot of the lee-side slope. 
TABLE I. SHAPES AND SURFACE CHARACTERISTICS OF LIGHTLY AND DEEPLY EMBEDDED BOULDERS, SKÁLAFELLSJÖKULL, SOUTH-EAST ICELAND

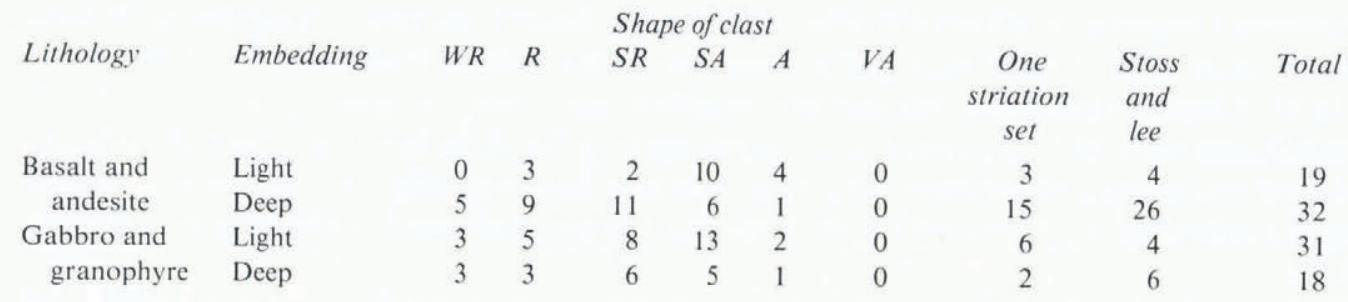

Shape classes follow Powers (1953):

WR Well rounded; R Rounded; SR Sub-rounded; SA Sub-angular; A Angular; VA Very angular.

different from that of lightly embedded boulders which had not ploughed into the lodgement till surface, a random sample of 50 lightly and 50 deeply embedded boulders greater than $0.3 \mathrm{~m}$ in diameter was selected. The study site was on the stoss slope of a roche moutonnee and had been deglaciated within the last 20 years. Boulders were classified as either coarse- or fine-grained igneous rocks. The former were either gabbro or granophyre, and the latter basalts or andesites. The roundness of each boulder was assessed using the visual classification of Powers (1953). If the boulder had a stoss-and-lee form, this was recorded and the long-axis orientation of the boulder was measured. If the boulder was striated, this was recorded and the orientation of the dominant striation set, if one existed, was measured. If the boulder was not striated or did not have a stoss-and-lee form, this was also recorded (Table I).

To determine the proportion of boulders in the till which had a stoss-and-lee form, and the influence of boulder size and lithology on this, 20 quadrats $1 \mathrm{~m}$ by $1 \mathrm{~m}$ were established on the till surface. In each quadrat, every clast with a B-axis diameter of more than $32 \mathrm{~mm}$ was examined, a total of 1 105. The lithology, B-axis diameter, and presence or absence of a stossand-lee form was recorded for each clast (Table II).

\section{Results}

There are no significant differences between lightly and deeply embedded boulders in terms of lithology, roundness, degree of striation, or degree of development of a consistently orientated striation set. Deeply embedded boulders are, however, more likely to have a stoss-and-lee form

Table II. Proportion of Clasts in SkÁlafells.ökull lodgement tills having Stoss-and-LeE Form, IN RELATION TO SIZE AND LITHOLOGY OF CLASTS

$\begin{array}{llllllllllll}\text { Lithology } & 30-59 & 60-89 & 90-119 & 120-149 & 150-179 & 180-209 & 210-239 & 240-269 & 270- & \text { Total } \\ \begin{array}{c}\text { Basalt and } \\ \text { andesite }\end{array} & 6.5 \% & 4.6 \% & 10.3 \% & 13.6 \% & 16.7 \% & 23.1 \% & 25 \% & 0 \% & 0 \% & 7.2 \% \\ \begin{array}{c}\text { Gabbro and } \\ \text { granophyre }\end{array} & 5.7 \% & 9.8 \% & 9.7 \% & 22.2 \% & 33.3 \% & 0 \% & 0 \% & 0 \% & 0 \% & 8.4 \% \\ \begin{array}{c}\text { Total } \\ \text { Number of cases }\end{array} & 6.3 \% & 585 & 271 & 10.2 \% & 15.1 \% & 18.5 \% & 16.7 \% & 20 \% & 0 \% & 0 \% & 7.8 \% \\ & & & & 53 & 27 & 18 & 5 & 5 & 13 & 1105\end{array}$


than lightly embedded boulders $\left(\chi^{2}=24.0, \mathrm{df}=3, p<0.005\right)$. Overall, $82(7.78 \%)$ of the 1105 clasts sampled had a stoss-and-lee form.

Lithology appears to influence boulder morphology. Lightly embedded fine-grained boulders are more likely to be striated than lightly embedded coarse-grained boulders $\left(\chi^{2}=12.45, \mathrm{df}=3\right.$, $p<0.01)$. Deeply embedded fine-grained boulders are more striated $\left(\chi^{2}=30.75\right.$, $\mathrm{df}=3$, $p<0.005)$ and more likely to have a stoss-and-lee form $\left(\chi^{2}=11.39, \mathrm{df}=3, p<0.01\right)$ than deeply embedded coarse-grained boulders. Lithology does not, however, affect the roundness of lightly or deeply embedded boulders, nor the proportions of lightly embedded boulders with stoss-andlee form.

Deeply embedded fine-grained boulders are more striated $\left(\chi^{2}=13.02, \mathrm{df}=3, p<0.005\right)$ and more likely to have a stoss-and-lee form than lightly embedded boulders of similar lithology $\left(\chi^{2}=17.95, \mathrm{df}=3, p<0.005\right)$. They are not, however, more rounded, or more likely to have a consistently orientated dominant set of striae. There are no differences in the roundness, degree of development of stoss-and-lee form, or striation of lightly and deeply embedded coarse-grained boulders.

$65 / 903$ fine-grained clasts had a stoss-and-lee form (7.19\%), compared with 17/199 coarsegrained clasts $(8.41 \%)$. Within each lithological class, the proportion of clasts with stoss-and-lee form increased with the B-axis diameter (Table II), so that larger clasts were more likely to have a stoss-and-lee form.

Sixty-five of the 100 boulders in the random sample were striated and their shapes were dominantly rounded to sub-angular. Only $8 / 100$ were angular or very angular, suggesting that virtually all had passed through the zone of traction at the glacier bed (Boulton, 1978). Observations on the distribution of debris in the adjacent glacier ice confirmed that large clasts are only present in the basal layers.

Excavation of five deeply embedded boulders showed that their lower surfaces had not been smoothed and streamlined in the same way as their upper surfaces. In several instances, fractured blocks were found at the foot of the lee surface of a boulder (e.g. Fig. 1), and in all 40 cases where boulders had a stoss-and-lee form, the lee surface was judged to be a clean fracture rather than a remanie surface.

To determine whether the long-axis orientation of boulders with stoss-and-lee form, and the orientation of their dominant striation set can in fact be used as indicators of ice-flow direction, these were analysed using 2-D vector analysis (Krumbein, 1939) and compared with ice-flow directions deduced from the orientation of bedrock striae. Vector magnitudes for the long-axis orientation of deeply embedded stoss-and-lee boulders and the direction of striations on them were significant at the 0.05 level. The directions of the resultant vectors were within $5^{\circ}$ of the direction of ice flow. Vector magnitudes for the long-axis orientation of lightly embedded stossand-lee boulders, and the direction of the dominant striation set on them, were not significant (Fig. 2).

\section{Discussion}

The stoss-and-lee form does seem to be a feature characteristic of deeply embedded boulders, though the frequency with which it occurs probably varies with boulder size and lithology. Large boulders are more likely to have a stoss-and-lee form than smaller ones, though they are less common in the till. The analysis of 50 lightly and deeply embedded boulders suggests that finegrained rocks are more likely to have a stoss-and-lee form than coarse-grained rocks, but this is 


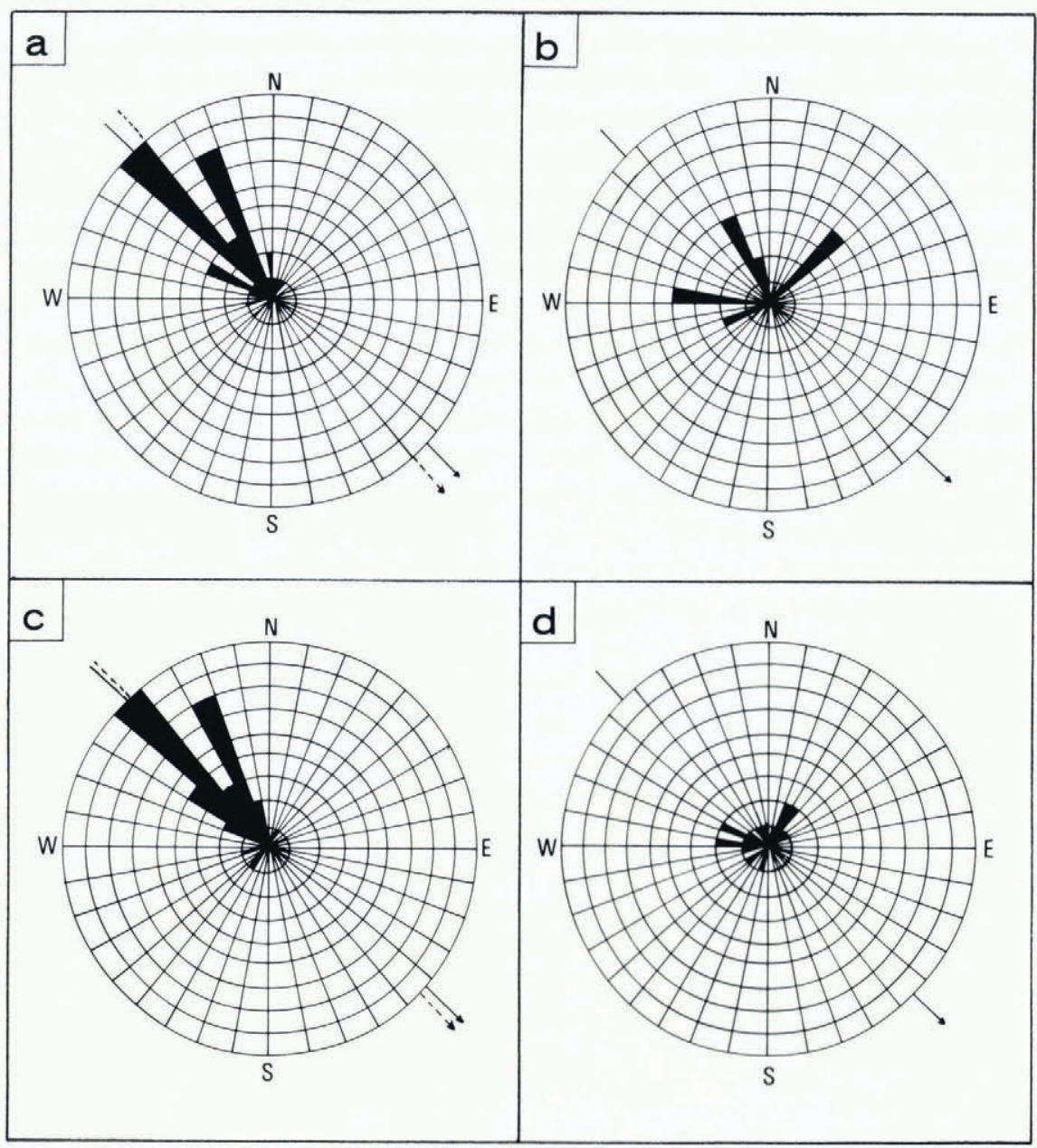

Fig. 2. a. Long-axis orientations of deeply embedded boulders with stoss-and-lee form. Vector magnitude $=63.2 \%$, $N=32$. b. Long-axis orientations of lightly embedded boulders with stoss-and-lee form. Vector magnitude $=7.5 \%, N=8$. c. Orientation of dominant striation set on deeply embedded boulders. Vector magnitude $=71.8 \%, N=30$. d. Orientation of dominant striation set on lightly embedded boulders. Vector magnitude $=18.8 \%, N=23$. Symbols: $\longrightarrow$ Ice-flow direction indicated by bedrock striae. $--\rightarrow$ Resultant vector.

not confirmed by the less detailed analysis of a further 1105 clasts. This discrepancy could be explained by a difference in the size distribution of clasts of the two lithologies.

The higher frequency of stoss-and-lee shapes among deeply embedded boulders, the increased rounding of deeply embedded fine-grained boulders, the fractured nature of boulder lee-side surfaces, the lack of modification of the lower surfaces of stoss-and-lee boulders, and the close alignment of the long axes of stoss-and-lee boulders with ice-flow direction all suggest that such boulder shapes develop in the way suggested by Boulton (1978). Modification of boulders by abrasion will occur if the debris particles in transport in the basal ice are as hard as or harder 
than the lodged boulder. The amount of modification which occurs will depend upon the concentration and rate of transport of debris particles in the glacier sole, and the length of time for which the boulder is exposed. Similar factors will control the likelihood of fracture occurring on the lee-side. Although lodgement tends to be concentrated around protruding obstacles at the glacier bed, it should still take longer to bury a large boulder than a small one, if only because rates of lodgement will decrease over time as the proportion of the boulder protruding decreases. Large boulders will therefore be exposed for longer and are more likely to be modified by erosion. This is confirmed by the results of this study (Table II).

The proportion of clasts in a till which develop a stoss-and-lee form will presumably thus depend upon the mix of lithologies in the till and the size distribution of clasts of each lithology, as well as the factors mentioned above. Hallet (1981) has shown that, as a result of drag between debris in traction and the glacier bed, the rate of basal sliding of a glacier may decrease as the concentration of debris in the glacier sole increases above $10 \%$. Rates of lodgement may also increase at such high debris concentrations as sliding rates drop to values equivalent to the rate at which basal ice melts due to geothermal heating. It is possible, therefore, that there is a critical value of debris concentration in the basal ice above which the chances of a deeply embedded boulder being modified subsequent to lodgement are much reduced.

Eight of the 50 lightly embedded boulders had a stoss-and-lee form, but their long axis orientations were highly variable and divergent from mean ice-flow direction at the site. They had probably once been deeply embedded but had since been incorporated and re-deposited by minor advances of the ice front responsible for constructing small push moraines (cf. Boulton and Paul, 1976, p. 168).

Two possible explanations are suggested for the observation that deeply embedded boulders are not more likely to have a single dominant striation set than lightly embedded boulders. Many of the fine-grained clasts have been derived very locally from polished and striated bedrock surfaces and may inherit a consistent striation set from them. Furthermore, Drake (1977) has shown that rod- and blade-shaped clasts may develop consistently orientated striae parallel to their long axes during transport at the glacier bed, because they experience very little clast rotation during transport.

The orientation of the long axis of clasts with stoss-and-lee form is closely related to the direction of ice flow, and the position of the lee-side surface makes it possible to determine the direction from which the ice was flowing. The orientation of striae on such deeply embedded clasts is also a good indicator of former ice-flow directions.

\section{ACKNOWLEDGEMENTS}

Thanks are due to the Icelandic National Research Council for permission to work at Skálafellsjökull. The work was carried out during tenure of a UK Natural Environment Research Council Studentship, and financial assistance was also given by the Royal Geographical Society. T. Asquith and J. Dowdeswell provided invaluable help and discussion in the field. Drs C. M. Clapperton and D. E. Sugden made helpful criticisms of earlier drafts. 


\section{REFERENCES}

Boulton, G. S. 1978. Boulder shapes and grain size distribution of debris as indicators of transport paths through a glacier and till genesis. Sedimentology, Vol. 25, No. 6, p. 773-99.

Boulton, G. S., and Paul, M. A. 1976. The influence of genetic processes on some geotechnical properties of glacial tills. Quarterly Journal of Engineering Geology, Vol. 9, No. 3, p. 159-94.

Drake, L. D. 1977. Depositional fabrics in basal till reflect alignments during transportation. Earth Surface Processes, Vol. 2, No. 4, p. 309-17.

Hallet, B. 1981. Glacial abrasion and sliding: their dependence on the debris concentration in basal ice. Annals of Glaciology, Vol. 2, p. 23-28.

Krüger, J. 1979. Structures and textures in till indicating subglacial deposition. Boreas, Vol. 8, No. 3, p. 323-40.

Krumbein, W. C. 1939. Preferred orientations of pebbles in sedimentary deposits. Journal of Geology, Vol. 47, No. 7, p. 673-706.

Powers, M. 1953. A new roundness scale for sedimentary particles. Journal of Sedimentary Petrology, Vol. 23, No. 2, p. $117-19$. 